Federal Reserve Bank of Minneapolis

Research Department Staff Report 146

November 1991

\title{
INTERNATIONAL REAL BUSINESS CYCLES
}

David K. Backus

New York University

\author{
Patrick J. Kehoe \\ University of Minnesota \\ and Federal Reserve Bank \\ of Minneapolis
}

Finn E. Kydland

Carnegie Mellon University

\begin{abstract}
We ask whether a two-country real business cycle model can account simultaneously for domestic and international aspects of business cycles. With this question in mind, we document a number of discrepancies between theory and data. The most striking discrepancy concerns the correlations of consumption and output across countries. In the data, outputs are generally more highly correlated across countries than consumptions. In the model we see the opposite.
\end{abstract}

We thank Andrew Atkeson, Lawrence Christiano, Beverly Lapham, and two referees for useful comments on an earlier draft, Klaus Neusser for help with data, Shawn Hewitt for timely and capable research assistance, Christian Zimmerman for pointing out a computational error, Kathy Rolfe for copyediting, and the National Science Foundation for financial support. An earlier version of this paper was circulated under the title "International Borrowing and World Business Cycles."

The views expressed herein are those of the authors and not necessarily those of the Federal Reserve Bank of Minneapolis or the Federal Reserve System. 
In closed-economy environments, real business cycle theory has accounted for many of the features of postwar U.S. business cycles. We consider an extension of this theory to open economies and ask whether it can account for both the comovements studied in closed-economy macroeconomics and salient international comovements, including correlations across countries of fluctuations in macroeconomic aggregates and movements in the balance of trade.

Quantitative studies of closed economies suggest that a stochastic growth model with a single aggregate technology shock can account for, among other things, the magnitude of fluctuations, relative to output, in consumption and investment and the correlations of these fluctuations with output. In the analogous world economy, countries experience imperfectly correlated shocks to their technologies. The interaction between these shocks and the ability to borrow and lend internationally can in principle have a substantial influence on the magnitude and character of aggregate fluctuations. In open economies, a country's consumption and investment decisions are no longer constrained by its own production. With respect to consumption, we might guess that the opportunity to share risk across countries would lead to equilibrium consumption paths that are both less variable and less closely related to domestic output than they are in closed-economy real business cycle models. With respect to investment, we might expect capital to be allocated to the country with the more favorable technology shock and thus generate greater variability in domestic investment.

The open-economy perspective also leads us to consider comovements with an international flavor. Perhaps the distinguishing feature of an open economy is that it can borrow and lend in international markets by running trade surpluses and deficits. The trade balance, which measures the difference between domestic production and absorption, can vary systematically over the cycle. Its cyclical properties are determined by the balance of two forces: the desire and ability of agents to smooth consumption using international markets and the additional cyclical variability of investment that international capital flows permit. These phenomena are reflected in the correlation 
between saving and investment rates as well. These rates are perfectly correlated in closed economies, but may be imperfectly correlated in open economies if countries use international markets to borrow and lend. The open-economy perspective also leads us to consider correlations across countries. The most obvious of these is the correlation between output fluctuations in different countries. Another such correlation is suggested by theory: with complete markets, we expect the ability to share risk internationally to produce a large correlation between consumption fluctuations across countries. Indeed, in some theoretical economies, this correlation is one, regardless of the correlation between outputs.

Thus, we ask whether an international version of a real business cycle model can account simultaneously for the familiar domestic comovements and several international comovements. We pay particular attention to statistics that relate directly to the allocative role of international markets: the cross-country correlations of consumption and output, the correlation of net exports with output, and the correlation between saving and investment rates.

Our model is a two-country extension of Kydland and Prescott's (1982) closed economy. To focus attention on the role of financial markets in allocating risk and determining intertemporal production decisions, we retain from their model the assumptions of a single homogeneous produced good and of complete markets for state-contingent claims. We depart from the original in two respects: countries experience different technology shocks each period, and agents participate in international capital markets. We allow innovations in the shocks to be correlated across countries. We also allow diffusion of technology shocks between countries, as technological change is transmitted across borders. In our experiments, we base the parameters measuring diffusion and correlation, as well as the variances of the shocks, on estimates of Solow (1957) residuals for the United States and an aggregate of European countries.

We find, in our benchmark economy, that openness alters substantially the nature of some of the closed-economy comovements. Consumption is somewhat smoother in this 
theoretical environment than it is in the data: the ratio of the standard deviation of consumption to that of output is 0.40 in the model and 0.49 in the U.S. data. Investment, in contrast, is much more volatile in the theoretical economy (10.94 vs. the data's 3.15). The contemporaneous cross correlation between investment and output is substantially smaller in the model than in the U.S. data (0.27 vs. 0.90$)$. For each of these properties, the closed-economy model is closer to the data, so in this sense, opening the economy has an important influence on its behavior.

We find similar differences between theory and data in the behavior of international comovements. The trade balance is much more variable in our model than it is in any of the major developed economies; the standard deviation of the ratio of net exports to output is 2.90 for the model, versus 0.79 for Canada, 0.85 for Germany, 0.89 for Japan, and 0.42 for the United States. Although output is positively correlated across most major countries, it is not in the theoretical economy; there the correlation is -0.18 . Consumption, however, is much more strongly correlated in the theory $(0.88)$ than in the data (where correlations range from -0.23 to 0.65 for various countries versus the United States).

Of these discrepancies, the large cross-country correlation of consumption relative to output is the most robust; most of the others evaporate with modest changes in parameter values or economic structure. In an attempt to account for the discrepancies, we conjecture that they may result from the ability of agents to trade assets and ship physical capital costlessly between countries. This ability is reflected in the large cross-country consumption correlation, the small or even negative cross-country output correlation, the large variability of investment and net exports, and the cyclical movements of investment and net exports - all of which differ from the data. This leads us to ask whether a world economy with small trading frictions would produce comovements more like those in the data. To this end we introduce into the model a small transportation cost on net trade between countries. This cost lowers substantially the variability of investment and net exports and produces strongly procyclical 
investment. It also reduces somewhat the difference between cross-country correlations of consumption and output, but unlike the data, the model's consumption correlation remains substantially larger than the output correlation. We also consider a more extreme experiment in the same spirit in which international borrowing is eliminated altogether. This experiment prohibits not only physical trade in goods, but also the trade in state-contingent claims that underlies international risk sharing. The quantitative properties of this experiment are very close to those with the small trading friction. This suggests that the consumption/output discrepancy is not simply the result of international risk sharing with complete markets.

This study is related to a growing body of work studying international business cycles from the perspective of dynamic general equilibrium theory, including papers by Cantor and Mark (1988), Dellas (1986), and Stockman and Svensson (1987). What we have done is given this work quantitative content by parameterizing a version of the theory and comparing its properties to those of international time series data.

We proceed as follows. In Section I we review the evidence on business cycles from an international perspective. In Section II we describe our theoretical world economy and characterize its equilibrium. In Section III we derive the economy's steady state and discuss settings of the model's parameters. With the exception of the parameters of the process governing technology shocks, the parameter values are taken from Kydland and Prescott's $(1982,1988)$ closed-economy studies and are therefore set without regard for their international implications. In Section IV we report cyclical properties of the model, and in Section $\mathrm{V}$ we introduce barriers to international trade in goods and assets. In the final section we summarize our findings and speculate on directions for further work.

\section{Properties of International Business Cycles}

We review the properties of international business cycles in developed economies for the postwar period. These properties refer to moments of quarterly time series detrended with the Hodrick-Prescott filter and to cross correlations between such series. This filter 
emphasizes the medium - and high-frequency movements in the data, those that most people associate with business cycles. For discussions of the properties of this and other filters, see Hodrick and Prescott (1980), King and Rebelo (1989), and Kydland and Prescott (1990). The Hodrick-Prescott filter has been used in earlier work by Backus and Kehoe (1988), Christiano and Eichenbaum (1988), Hansen (1985), Kydland and Prescott (1982, 1988, 1990), and Prescott (1986) to summarize fluctuations in aggregate data. Its effect is illustrated in figure 1 for the logarithm of U.S. real output. Our statistics refer to deviations of the raw data from the trend identified by the Hodrick-Prescott filter, which in figure 1 is the difference between the two lines.

Table 1 reports cyclical properties of the U.S. economy between 1954 and 1989. Note that the standard deviation of output fluctuations is 1.71 percent. We shall use this figure as a basis of comparison with the theoretical economy. Consumption of nondurables and services is about half as volatile as output, investment in fixed capital is more than three times as volatile as output, and hours worked is slightly less volatile than output. All three of these series are strongly procyclical. The final row of table 1 summarizes the cyclical behavior of the trade balance, measured here as the ratio of net exports to output. The trade balance has been countercyclical, with a contemporaneous correlation with output of -0.28 . Many of these properties are documented for other developed countries in Danthine and Donaldson (forthcoming).

Table 2 reports some international statistics for twelve developed countries (the universe of usable quarterly data from International Financial Statistics) and a European aggregate described in the Appendix. The table first lists the contemporaneous correlation of output fluctuations between each country and the United States. These vary in size but, except for one, are positive. The exception is South Africa. The correlations for Japan and the major European countries lie between 0.22 and 0.48 . The table next lists analogous cross-country correlations for consumption. These, too, vary across countries, but are all smaller than the output correlations. The largest correlation is 0.65 for Canada. The consumption correlation between the United States and the 
European aggregate is 0.46 , which is substantially smaller than the output correlation of 0.70. The difference between the European aggregate correlations and the correlations for the individual countries is to some extent an artifact of the shorter sample period used in the calculations for the aggregate: there is greater correlation across countries in the 1970 s than in the 1960 s or 1980 s. However, the relation between the output and consumption correlations is the same for the aggregate and the individual countries: the correlation is stronger between outputs than between consumptions.

Our interest in the consumption correlation stems from a well-known property of complete markets: in economies with one good and stationary, additively separable preferences, consumption by every agent is deterministically and positively related to consumption by every other agent. If preferences are identical and homothetic, the relation is linear: the consumption paths of any two agents are perfectly correlated, regardless of the correlation of their incomes. Scheinkman (1984) suggests that the correlation of consumption across countries is a direct measure of how well such models mimic the international economy.

The third column of table 2 reports the correlations between saving and investment rates within countries. Feldstein and Horioka (1980) have shown, using regressions with cross-section data at low frequencies, that saving and investment are very highly correlated. They interpret this fact as challenging the assumption that world capital markets are perfectly integrated. Their intuition is that Fisher separation implies that, in open economies, saving and investment decisions need not match if capital is internationally mobile, yet the correlation in the data is large. Many studies, including those of Dooley, Frankel, and Mathieson (1987), Obstfeld (1986), and Tesar (1991), have shown the empirical relation to be extremely robust at low frequencies. Obstfeld (1986) and Tesar (1991) have found less regularity in the high-frequency movements on which we focus.

One problem we face in relating the saving/investment correlation to a theoretical model is that the definition of saving, unlike the other variables we have looked at, is 
sensitive to the market structure used to decentralize equilibrium allocations. From a theoretical point of view, saving depends not only on equilibrium prices and quantities, but also on the asset structure used to decentralize the equilibrium allocations. Another problem is empirical. Perhaps the most obvious definition of a country's saving is the change in the market value of its wealth. These market values depend on the asset structure and are notoriously hard to measure. Most definitions of saving, including that of the national income and product accounts of the United States and many other countries, are based on more easily implemented concepts. The standard definition, for example, is household receipts minus expenditures; it does not include capital gains or losses on assets. A related difficulty led us earlier to study net exports, rather than the current account, as our measure of international flows. The current account contains, in addition to exports and imports, interest payments and changes in the market values of internationally traded assets that are almost impossible to measure accurately. (See, for example, Taylor's (1989) comments on the worldwide current-account imbalance.) Imports and exports, on the other hand, are relatively easy to measure in both the data and the theory. We take a similar approach to saving. Rather than attempt to replicate in our model a theoretically ambiguous variable, we define a new variable and compare its behavior in the model and the data. Our saving is output minus consumption and government purchases, all of which are measured easily in both the data and our theoretical economy. This definition captures the separation between saving and investment in open economies that motivated the Feldstein-Horioka (1980) study, so it retains the appeal of conventional measures. In table 2 we find, as do Obstfeld (1986) and Tesar (1991) with a similar definition, that the correlation between saving and investment rates varies widely across countries, but is large and positive for Germany, Japan, and the United States.

The last two columns of table 2 pertain to net exports. We measure trade, again, as the ratio of net exports to output and its variability as the standard deviation of this ratio. These measures vary over time and across countries. For each of the countries in 
table 2 the ratio of net exports to output is countercyclical, in the sense that its contemporaneous correlation with output is negative. The countercyclical movement of the balance of trade has been documented in annual data by Backus and Kehoe (1988) for the periods prior to World War I and between the wars for Australia, Canada, Norway, Sweden, the United Kingdom, and the United States. Dellas (1986) has found the same pattern in postwar data using spectral methods. It is also implicit in empirical work in the Keynesian tradition, like that by Krugman and Baldwin (1987), in the strong income term in import-demand equations.

We summarize briefly. Business cycles exhibit a great deal of regularity across countries. Investment is much more volatile than output, consumption is less volatile than output, hours worked about as volatile as output, and all three variables are procyclical. In the twelve countries we have investigated, net exports is consistently countercyclical. Output fluctuations are more highly correlated across countries than are consumption fluctuations. The correlations between saving and investment rates show no clear pattern.

\section{A World Economy}

Our theoretical world economy consists of two countries, each represented by a large number of identical consumers and a production technology. The countries produce the same good, and their preferences and technologies have the same structure and parameter values. Although the technologies have the same form, they differ in two important respects: in each country, the labor input consists only of domestic labor, and production is subjected to country-specific technology shocks.

The preferences and technology in each country are, with one exception, those of the single country in Kydland and Prescott's (1982) closed-economy model. In the home (h) and foreign (f) countries, the stand-in consumer maximizes the expected utility function:

$$
\mathrm{E}_{0} \sum_{t=0}^{\infty} \beta^{\mathrm{t}} \mathrm{U}\left(\mathrm{c}_{\mathrm{t}}^{\mathrm{i}}, \overline{\mathrm{e}}_{\mathrm{t}}^{\mathrm{i}}\right), \quad \text { for } \mathrm{i}=\mathrm{h}, \mathrm{f},
$$


where $\mathrm{U}(\mathrm{c}, \ell)=\left[\mathrm{c}^{\mu} \ell^{1-\mu}\right]^{\gamma} / \gamma$. Here $0<\mu<1, \gamma<1, \mathrm{c}_{\mathrm{t}}^{\mathbf{i}}$ is consumption of the produced good and $\ell_{\mathrm{t}}$ is a distributed lag on leisure. Leisure is interpreted as the amount of time, net of sleep and personal care, allocated to nonmarket activities. The case $\gamma=0$ corresponds to logarithmic utility. With the time endowment normalized at one, the distributed lag on leisure is defined by

$$
\ell_{\mathrm{t}}=1-\alpha \mathrm{n}_{\mathrm{t}}-(1-\alpha) \eta \mathrm{a}_{\mathrm{t}} \text { and }
$$

$$
a_{t+1}=(1-\eta) a_{t}+n_{t}
$$

where $\mathrm{n}$ is time allocated to work, $0<\eta \leq 1$, and $0<\alpha \leq 1$. The variable $\mathrm{a}_{\mathrm{t}} \equiv$ $\Sigma_{j=1}^{\infty}(1-\eta)^{j-1} n_{t-j}$ summarizes the influence of past leisure choices on current utility. When $\alpha=1, \ell_{t}=1-n_{t}$ and current utility depends only on current leisure; when $\alpha<1$, current utility depends, in part, on previous nonmarket time, with weights determined by $\eta$.

Production of the single good takes place in each country using inputs of capital $k$, labor $\mathrm{n}$, and stocks of inventories $\mathrm{z}$. It is affected by a technology shock $\lambda>0$. Output in country $i$ is $y_{t}^{i}=F\left(\lambda_{t}^{i}, k_{t}^{i}, n_{t}^{i}, z_{t}^{i}\right)$, where

$$
F(\lambda, k, n, z)=\left[\left(\lambda k^{\theta} n^{1-\theta}\right)^{-\nu}+\sigma \mathbf{z}^{-\nu}\right]^{-1 / \nu}
$$

$0<\theta<1, \nu>-1$, and $\sigma>0$. Our nesting of capital and labor is slightly different from that in Kydland and Prescott (1982) and follows instead their 1988 paper. Here the technology shock affects the productivity of the capital/labor aggregate. World output from the two processes, $F\left(\lambda_{t}^{h}, k_{t}^{h}, n_{t}^{h}, z_{t}^{h}\right)+F\left(\lambda_{t}^{f}, k_{t}^{f}, n_{t}^{f}, z_{t}^{f}\right)$, is allocated to consumption, fixed investment, and inventory accumulation:

$$
\Sigma_{i}\left(c_{t}^{i}+x_{t}^{i}+z_{t+1}^{i}-z_{t}^{i}\right)=\Sigma_{i} F\left(\lambda_{t}^{i}, k_{t}^{i}, n_{t}^{i}, z_{t}^{i}\right)
$$


Net exports is $n x_{t}^{i}=y_{t}^{i}-\left(c_{t}^{i}+x_{t}^{i}+z_{t+1}^{i}-z_{t}^{i}\right)$.

The technology incorporates the time-to-build structure emphasized by Kydland and Prescott (1982). Additions to the stock of fixed capital require inputs of the produced good for J periods, or

$$
\begin{aligned}
& k_{t+1}^{i}=(1-\delta) k_{t}^{i}+s_{1 t}^{i} \\
& s_{j, t+1}^{i}=s_{j+1, t^{i}}^{i} \text { for } j=1, \ldots, J-1,
\end{aligned}
$$

where $\delta$ is the rate of depreciation and $\mathrm{s}_{\mathrm{jt}}^{\mathrm{i}}$ is the number of investment projects in country $i$ at date $t$ that are $j$ periods from completion. We denote by $\phi_{\mathbf{j}}$, for $\mathbf{j}=1, \ldots, \mathrm{J}$, the fraction of total value added to an investment project in the jth period before completion. We set $\dot{\phi_{j}}=1 / \mathrm{J}$, so that an investment project leading to an addition of one unit to the capital stock at date $t+1$ requires the sequence of equal expenditures

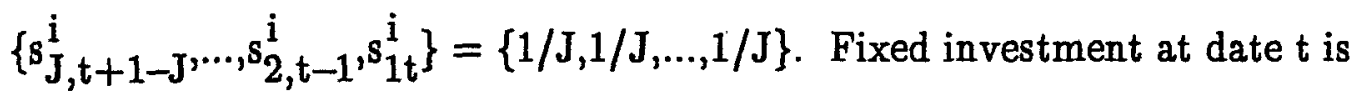

$$
x_{t}^{i}=\sum_{j=1}^{J} \phi_{j} s_{j t}^{i},
$$

the sum of investment expenditures on all existing projects.

We depart from Kydland and Prescott in specifying the technology shock process for the two countries as a bivariate autoregression,

$$
\lambda_{\mathrm{t}+1}=\mathrm{A} \lambda_{\mathrm{t}}+\epsilon_{\mathrm{t}+1}
$$

where $\lambda_{\mathrm{t}} \equiv\left(\lambda_{\mathrm{t}}^{\mathrm{h}}, \lambda_{\mathrm{t}}^{\mathrm{f}}\right), \mathrm{A}$ is a matrix of coefficients, and $\epsilon_{\mathrm{t}} \equiv\left(\epsilon_{\mathrm{t}}^{\mathrm{h}}, \epsilon_{\mathrm{t}}^{\mathrm{f}}\right)$. The innovations $\epsilon_{\mathrm{t}}$ are serially independent, multivariate, normal random variables with contemporaneous covariance matrix $\mathrm{V}$, which allows contemporaneous correlation between the home and 
foreign innovations. Thus, the shocks are stochastically related through the off-diagonal elements of $A$ and $V$. We refer to the off-diagonal elements of $A$ as spillovers, since they indicate the extent to which shocks to one country's technology spill over in later periods to the other country. We assume that the vector $\lambda_{t}$ is known by agents when they make their date-t decisions. We have eliminated from the original Kydland and Prescott (1982) formulation the temporary technology shock and the indicator shock. These features have little influence on the international properties of the economy.

We characterize an equilibrium in this world economy by exploiting the equivalence between competitive equilibria and Pareto optima. Since the utility functions are concave, any optimum can be computed as the solution to a planning problem of the form: maximize

$$
\psi \mathrm{E} \sum_{t=0}^{\infty} \beta^{t} U\left(c_{t}^{h}, l_{t}^{h}\right)+(1-\psi) E \sum_{t=0}^{\infty} \beta^{t} U\left(c_{t}^{f}, \ell_{t}^{f}\right)
$$

subject to the constraints (1)-(7), for some choice of $0<\psi<1$. As do Mantel (1971) and Negishi (1960), we associate a competitive equilibrium with the solution to this problem for each choice of $\psi$. We compute the competitive equilibrium associated with $\psi=1 / 2$.

Operationally, we approximate the planning problem in the neighborhood of the steady state. First we eliminate the single nonlinear constraint, equation (3), by substituting it into the objective function (8). After constructing a quadratic approximation of the resulting function, we maximize it subject to the remaining constraints.

\section{Steady State and Parameter Values}

We are interested in the properties of our theoretical world economy when both countries have the same structure and parameter values as the single economy of Kydland and Prescott (1982, 1988). Except for the parameters describing the stochastic relationship between home and foreign technology shocks, summarized by the matrix $A$ of 
coefficients and the covariance matrix V, we use the values that Kydland and Prescott used in their closed-economy real business cycle studies. Here, the parameters of the technology $\rightarrow$ hock process are estimates from international data, so none of the parameter values are chosen to help the model match international business cycle experience.

A steady state for this economy is its rest point when the variances of the shocks are zero. Most of the parameters in the Kydland-Prescott studies were set to match steadystate relations for the model with postwar averages of U.S. time series. Since the world economy is symmetric, its steady state is simply that of the closed economy replicated twice. We proceed to derive the model's steady state and describe how data on means and growth rates of economic time series can be used to restrict the values of the parameters.

In the steady state, levels of consumption, labor, the stock of capital, and inventories are constant. The steady-state real rate of interest is, thus, $\mathbf{r}=(1-\beta) / \beta$. In the steady state, fixed investment equals depreciation and inventory investment is zero. The resource constraint is, then, $c+\delta \mathbf{k}=\mathrm{y}$. The rental price of inventories is just the real interest rate, $r$. The value of resources used to produce one unit of capital in terms of the same-date consumption good is $q=\sum_{j=1}^{J} \phi_{j}(1+r)^{j-1}$. The rental price of capital is, therefore, $q(\mathbf{r}+\delta)$. A profit-maximizing firm's first-order conditions for inventories, capital, and labor imply

$$
\begin{aligned}
& \mathrm{r}=\sigma(\mathrm{y} / \mathrm{z})^{1+\nu}, \\
& \mathrm{q}(\mathrm{r}+\delta)=\theta(\mathrm{y} / \mathrm{k})\left[1-\sigma(\mathrm{y} / \mathrm{z})^{\nu}\right], \\
& \mathrm{w}=(1-\theta)(\mathrm{y} / \mathrm{n})\left[1-\sigma(\mathrm{y} / \mathrm{z})^{\nu}\right],
\end{aligned}
$$

where $w$ is the equilibrium wage in consumption units, determined jointly with the stand-in consumer's problem. From the consumer's first-order condition, $U_{\ell} / U_{c}=w$, we obtain 


$$
(1-\mu) c(\alpha r+\eta) /(r+\eta)=\mu w(1-n)
$$

This completes the derivation of the steady state and illustrates its relation to the model parameters.

We use information about secular movements from national income and product accounts and from micro observations to restrict the model's parameters and functional forms. Steady-state consumption as a fraction of output is three-quarters $(c / y=0.75)$, and investment is one-quarter $(x / y=0.25)$. The mean of the inventory/output ratio is one $(z / y=1)$ with output measured at a quarterly rate. The steady-state real interest rate, $r$, is set equal to one percent per quarter, which is close to the average rate of return on capital over the past century. This implies $\beta=1 /(1+r) \cong 0.99$.

The technology parameters are based on the following considerations. The Cobb-Douglas form of capital/labor substitution is chosen to match the relative constancy of the share of output going to labor despite large secular increases in the real wage. The shares going to capital and labor in the model are, then, approximately $\theta$ and $1-\theta$, respectively. In postwar U.S. data, the share going to labor is about 0.64 , so we set $1-\theta=0.64$. Aggregate data indicate a depreciation rate, $\delta$, of 0.025 , which implies a capital/output ratio of 10 . The values of the real interest rate and the inventory/output ratio imply, by equation (9), that $\sigma=0.01$. With this value the share of output going to inventories is about one percent. The technology parameter $\nu$, which determines the elasticity of substitution between inventories and the capital/labor aggregate, cannot be determined from steady states alone. Kydland and Prescott (1988, p. 351) set $\nu=3$ and cite observations at the firm level. This feature has little effect on the international aspects of the model. That leaves us with the length of time to build. We follow Kydland and Prescott (1982) in setting $\mathrm{J}=4$.

Now consider preferences. The Cobb-Douglas specification between consumption and leisure is selected because, despite an enormous increase in the real wage, the per-household fraction of time allocated to market activities has changed very little over 
the postwar period. The share parameter, $\mu$, is chosen to be consistent with an average hours allocation of 30 percent of the endowment of nonsleeping time to market activities. The value implied by equation (10) when $\alpha=1$ is 0.34 . The curvature parameter, $\gamma$, determines the household's coefficient of relative risk aversion and intertemporal elasticity of substitution. Statistical evidence from U.S. time series, as in Eichenbaum, Hansen, and Singleton (1988), suggests that a value between -2 to 0.5 is appropriate. We use $\gamma=-1$. The absence of additive separability implied by nonzero values of $\gamma$ is potentially important in allowing the economy to account for one of the regularities of international data: the imperfect correlation between consumption fluctuations across countries. With logarithmic utility, which corresponds here to $\gamma=0$, the period utility function is additively separable and the correlation is one; with other values the correlation is smaller. In all but one of our experiments, we eliminate the distributed lag on leisure by setting $\alpha=1$. This feature of the economy has, as we show, little effect on the international dimensions of the economy. The evidence of Hotz, Kydland, and Sedlacek (1988), however, suggests that $\alpha=0.6$ and $\eta=0.1$ may be more appropriate, and one of our experiments uses these values.

The extra ingredient in the two-country economy is the interaction between foreign and domestic technology shocks. We estimated the parameters of the bivariate shock process using estimates of Solow (1957) residuals for the United States and for an aggregate of major European countries (Austria, Finland, Germany, Italy, Switzerland, and the United Kingdom). The logarithms of the Solow residuals are estimated as $\log \lambda$ $=\log \mathrm{y}-(1-\theta) \log \mathrm{n}$ from aggregate data on output $\mathrm{y}$ and employment $\mathrm{n}$, and are normalized so that the mean of $\lambda$ is one. Details are given in the Appendix. The absence of capital stock data for this calculation is probably not a serious problem. Experience indicates that the short-run variability of the capital stock is small and orthogonal to the cycle (table 1). We would prefer to have measures of hours worked, as well as employment, but most countries do not construct comprehensive hours series. Many countries report hours data for manual workers in manufacturing, but we know from U.S. 
data that manufacturing hours are a small part of the total and are significantly more volatile.

Given these values for $\lambda$, then, we estimate by least squares the parameters of equation (7) for the United States and our European aggregate, with the United States as the home country. The sample period is $1970: 1$ to $1986: 4$, which is all the available data. Our estimates are

$$
\mathrm{A}=\left[\begin{array}{ll}
.904(.073) & .052(.041) \\
.149(.064) & .908(.036)
\end{array}\right]
$$

where the numbers in parentheses are standard errors. The standard deviations for innovations to U.S. and European productivity are 0.00906 and 0.00797 , respectively, and the correlation between the innovations is 0.258 . The estimated matrix $A$ has eigenvalues of 0.994 and 0.818 . We estimate the same structure with Solow residuals for the United States and Canada over the same period. In this case the estimates are

$$
\mathrm{A}=\left[\begin{array}{ll}
.796(.079) & .131(.052) \\
.000(.093) & .989(.060)
\end{array}\right]
$$

with standard deviations of 0.00874 and 0.01023 and a correlation between innovations of 0.434. The eigenvalues are 0.989 and 0.796 , which are similar to those we found for the United States and Europe. Note that in both systems, estimates of the spillover effect, the off-diagonal elements of $\mathrm{A}$, are generally positive: shocks to productivity in one country produce gradual movements in the same direction in the other country.

We use several settings for the parameters of the technology process in our computational experiments, including the estimates for the United States and Europe reported above. For our benchmark case, however, we use a symmetrized version of these estimates. This fits in with the symmetry of the model and allows us, among other things, to summarize the properties of the model by reporting statistics for a single country. The unique symmetric matrix A with eigenvalues 0.994 and 0.818 is 


$$
\mathrm{A}=\left[\begin{array}{ll}
.906 & .088 \\
.088 & .906
\end{array}\right]
$$

For both countries, the standard deviation of the innovations is set equal to 0.00852 , the average of the two values estimated in the U.S.-European system. The correlation between innovations is set equal to 0.258 , as estimated.

\section{Findings}

We turn to the quantitative properties of our theoretical world economy, starting with the benchmark parameter values discussed in Section III and listed in table 3 . Tables 4 and 5 report means and standard deviations of sample moments computed from 50 simulations of the economy, each of 100 periods. The number 100 corresponds, approximately, to the average sample length used to compute the international comovements reported in table 2. As with the data in Section II, the statistics in our experiments refer to Hodrick-Prescott filtered variables.

The properties of the theoretical world economy with the benchmark parameter values are reported in table 4. The standard deviation of output fluctuations in this economy is 1.55 percent, which is 91 percent of the standard deviation of U.S. output reported in table 1. The behavior of several of the output components, however, is quite different from that in the data. Although the variability of consumption relative to output is only slightly smaller in the model economy than it is in U.S. data (0.40 vs. 0.49), the variability of investment relative to output is more than three times larger (10.94 vs. 3.15). With respect to international comovements, the standard deviation of the trade balance is about seven times larger in the model economy than it is in U.S. data and much larger than it is in the data for any country in table 2. The trade balance is essentially uncorrelated with output (with a contemporaneous correlation of -0.02 ), and not as strongly countercyclical as it is in most of the economies of table 2. Saving and investment rates are positively correlated in the model, but not strongly so. In the data there is no obvious regularity in these high-frequency movements. Foreign and domestic 
output are negatively correlated in the model, while in the data they are positively correlated in all but one of the twelve countries. Also, foreign and domestic consumption are much more highly correlated in the model than they are in the data. In the model, unlike the data, the consumption correlation (0.88) far exceeds the output correlation $(-0.18)$.

We can get some intuition for these properties of the model by examining the dynamic responses to innovations pictured in figure 2. This figure illustrates the response of the benchmark economy to a one-time one-standard-deviation shock to the home country's technology innovation $\epsilon^{\mathrm{h}}$, starting from the steady state. In the figure, productivity is measured as a percentage of its steady-state value; the remaining variables are measured as percentages of steady-state output. The first panel of figure 2 shows what happens in the home country. There, the technology innovation is followed by a rise in productivity that slowly decays. The increase in productivity is associated with increases in domestic investment, consumption, and output. The movement in investment is by far the largest, and it leads to a deficit in the balance of trade. That is, the rise in investment plus consumption is larger than the rise in output, with the difference accounted for by imports from the foreign country.

As we see in the second panel of figure 2, the innovation to domestic productivity leads eventually, through the technology spillover, to a rise in foreign productivity. Despite this, foreign output and investment both fall initially. Roughly speaking, resources are shifted to the more productive location, the home country. This happens both with capital, as investment rises in the home country and falls abroad, and with labor (not shown), which follows the same pattern. Foreign consumption, however, rises slightly. Thus we see that the equilibrium responses of foreign and domestic consumption have the same sign, but those of foreign and domestic output do not. This helps to explain the negative correlation between foreign and domestic output that we saw in table 4. 
The benchmark economy, then, differs from postwar international data in several respects. In the model, investment and net exports are more variable, while consumption is more highly correlated across countries and output is less highly correlated. The question is whether these discrepancies are sensitive to modest changes in the model's parameter values or theoretical structure. Examples of each are reported in Table 5. The first experiment following the benchmark economy is labeled asymmetric spillovers; in it, we use the asymmetric estimate of A obtained from Solow residuals for the United States and our European aggregate. In this experiment, the reported statistics are those of the home country. The largest differences from the benchmark economy involve investment: the investment/output correlation drops from 0.27 to -0.08 , and the saving/investment correlation drops from 0.28 to -0.04 . In the foreign country, however, these correlations (not reported in the table) are, respectively, 0.39 and 0.34 . Clearly, the saving/ investment correlation is sensitive to modest perturbations of the technology process. We also find that investment and net exports are still much more variable than they are in the data and consumption remains more highly correlated across countries than output.

With other choices of A the economy's behavior can be quite different. We guessed that some of these discrepancies might be moderated by raising the correlation between the shocks, either by increasing the spillovers between technology shocks (the off-diagonal elements of A) or by increasing the covariance between technology innovations (the off-diagonal elements of $\mathrm{V}$ ). In the large spillovers experiment, we consider an extreme example, raising the off-diagonal element of $\mathrm{A}$ from 0.088 to 0.2 , and the correlation between innovations from 0.258 to 0.5 . These changes probably go beyond what can be justified from the data, even with due consideration for the sampling variability of our estimates and the possibility of measurement error in the Solow residuals. We find that with these parameter values, investment and net exports are much less volatile: their standard deviations, relative to output, fall more than 70 percent. We also find that the correlation between foreign and domestic output rises, from -0.18 in the benchmark 
economy to 0.38 . At the same time, the consumption correlation moves further away from that in the data, rising from 0.88 to 0.95 . In this last respect the model still has a large discrepancy with the data.

The next three experiments illustrate the effects on the economy of increasing risk aversion, adding a distributed lag on leisure, and reducing the length of time-to-build. Our intuition was that the first two changes would magnify the effect of the nonseparability in utility between consumption and leisure and therefore lower the correlation of consumption across countries. Increasing risk aversion, by lowering $\gamma$ from -1 to -5 , has only a small downward effect on the volatility, relative to output, of investment and net exports. It raises the cross-country output correlation from -0.18 to -0.11 and lowers the consumption correlation from 0.88 to 0.74 , but the consumption correlation still far exceeds the output correlation. The distributed lag on leisure, which makes leisure durable, increases the variability of output and investment. It raises the intertemporal substitutability of leisure and leads, as it does in Kydland and Prescott's (1982) closed-economy study, to more volatile hours in equilibrium: the standard deviation of hours relative to output rises from the benchmark's 0.49 to 0.67 (not reported in the table). This leads to greater variation in the marginal product of capital at a given level of the capital stock, thus raising the variability of investment relative to output from 10.94 to 12.81 . The distributed lag, however, has little effect on the difference between cross-country output and consumption correlations.

Time-to-build has a strong influence on the model's properties. With $J=1$ instead of 4 , so that investment made in one quarter raises the capital stock the next quarter instead of a year later, the standard deviation of output rises 45 percent to 2.24 . The standard deviation of investment relative to output, which in the benchmark economy is three times larger than in the data, is now 10 times larger. In the closed economy, the variability of investment is not very sensitive to the choice of $\mathrm{J}$ : the standard deviation is about the same with $J=1$ as with $J=4$. As a result, Christiano and Eichenbaum (1988), Hansen (1985), and others use the simpler one-quarter construction period in 
closed-economy studies. In this respect, the length of time-to-build is more critical in the open economy.

\section{Trading Frictions}

We continue our sensitivity analysis by considering modifications to the theoretical structure. Our intuition is that the largest discrepancies we have found between theory and data reflect the ability of agents in the model to shift resources across countries and to trade in markets for state-contingent claims. The ability to shift resources allows agents to shift capital and production effort to the country with the higher current technology shock; that movement shows up in the model as excessive variability of investment and negative correlation of output across countries. Consumers' ability to insure themselves against adverse movements in their own technology shocks suggests that the shifting of production will not be reflected in consumption plans.

We, therefore, investigate frictions in the physical trading process and, in one extreme experiment, the market structure. We start by adding a trading friction, which we interpret as a transport cost. In its original form, the resource constraint, equation (3), implies that goods are freely and costlessly transferred between countries. Here we consider a modified version of this constraint that includes a small cost to shipping goods across the border. A linear transport cost on net exports leads, in the aggregate, to a $V$-shaped cost function on the absolute value of net exports, since net exports for one country are net imports for the other. This introduces a corner into the planner's problem that is not easily approximated by our quadratic approximation. Instead, we approximate this cost with a quadratic function of net exports,

$$
\mathrm{G}(\mathrm{nx})=\tau \mathrm{nx}^{2}
$$

where $\tau>0$ is a parameter. The resource constraint, equation ( 3 ), becomes

$$
\Sigma_{i}\left(c_{t}^{i}+x_{t}^{i}+z_{t+1}^{i}-z_{t}^{i}\right)=\Sigma_{i} F\left(\lambda_{t}^{i}, k_{t}^{i}, n_{t}^{i}, z_{t}^{i}\right)-\Sigma_{i} G\left(n x_{t}^{i}\right) .
$$


The parameter $\tau$ determines the cost of trade: the marginal cost is $2 \tau \mathrm{nx}$ in each country. We use $\tau=0.1 / \mathrm{y}$, where $\mathrm{y}$ is steady-state output. This corresponds to a marginal cost of 0.580 percent in each country at $\mathrm{nx} / \mathrm{y}=0.0290$, the standard deviation of $\mathrm{nx} / \mathrm{y}$ in the economy without the transport cost.

Properties of the model with this friction are reported in table 5 under the heading transport cost. This cost is very successful in reducing the variability of trade: the standard deviation of fluctuations in the ratio of net exports to output drops from the benchmark economy's 2.90 percent to 0.16 percent. The transport cost also lowers the standard deviation of investment relative to output by a factor of four, to 2.60 . The standard deviation of output falls from 1.55 to 1.38 , and output's correlation across countries rises from -0.18 to 0.02 . The cross-country correlation of consumptions rises slightly, from 0.88 to 0.91 . In short, this type of friction greatly reduces the variability of net exports and investment, but has little effect on the difference between the crosscountry correlations of consumption and output.

Next we eliminate from the model all trade in goods and assets, the experiment labeled autarky in table 5. Here the only connection between countries is the correlation between technology shocks. This friction eliminates both physical trade between countries and trade in state-contingent claims. In the table we see that this extreme experiment reduces the variability of output further, to 1.33 from 1.38 in the model with transport costs. Otherwise, the autarky experiment is very close to the experiment with small trading frictions. As in that experiment, the correlation between saving and investment rates is large. In autarky, this correlation would be exactly one if the model did not have inventories. Note, too, that even with trade fixed at zero, the correlation of consumption across countries is much higher than the correlation of output. This discrepancy, therefore, cannot be attributed to imperfect capital markets alone, since no assets are traded in this world.

Figure 3 illustrates the dynamic responses in the autarky economy to a onestandard-deviation shock to domestic technology - the same experiment we examined in 
figure 2. The response of the technology shocks, $\lambda^{\mathrm{h}}$ and $\lambda^{\mathrm{f}}$, are the same as we saw earlier, but other responses are restricted by the complete absence of trade. Note, first, that the magnitude of the response of domestic investment is much smaller in this economy than it was under free trade (the benchmark economy). Just as before, however, investment initially moves in opposite directions in the two countries. Note also that consumption increases in both countries. Under free trade, our intuition was that the positive correlation of consumption in the two countries reflected international risk-sharing arrangements. Under autarky, though, these arrangements are prohibited, yet we see the same positive correlation. This correlation thus seems to reflect, instead, the operation of the permanent income hypothesis. The foreign agent knows that a rise in productivity in the home country will spill over to the foreign country and raise his own future productivity and income. In anticipation of this, he chooses to increase consumption immediately and postpone some investment.

A surprising feature of these two experiments is that a small trading cost produces most of the properties of autarky. A possible explanation comes from Cole and Obstfeld (1991): if the gains from trade are small, then a small cost may have a large effect on the quantity of trade in goods and assets. To investigate this for our model, we measure the gains from trade by comparing equilibria in the benchmark (free trade) economy to the autarky economy. We express the welfare gain as the percentage increase in the consumption path under autarky necessary to reach the same level of welfare attained with free access to international markets. Welfare in each case is estimated as the mean value of discounted utility over the 50 replications of 100 periods each. We find that consumption in autarky must be increased only 0.3 percent to make consumers as well off as they are when international markets are open. The welfare gains from trade in our theoretical economies stem solely from trade across states and dates. As in similar calculations by Cole and Obstfeld, the gains are remarkably small, which may help to account for the large effect of a small trading cost on the model's equilibria. 


\section{Final Remarks}

Real business cycle theory in closed economies has been used to examine the effect of technology shocks on aggregate fluctuations. In this paper, we have extended that theory to a competitive model of a world economy with a single homogeneous good and internationally immobile labor. This extension changes the character of aggregate fluctuations considerably. In our theoretical open economy, consumption is more highly correlated across countries, output is less highly correlated across countries, and investment and the trade balance are much more volatile than we see in the data. When small trading frictions are introduced, the volatilities of investment and net exports fall sharply. The consumption/output discrepancy, however, is much more robust. In all of our experiments - including those with trading frictions, small or prohibitive, and those with several alternative parameter settings - the cross-country correlation of consumption remains substantially larger than the output correlation. In the data the output correlation is generally larger. Since this feature is robust to a number of reasonable changes in the economy, we label it an anomaly.

The consumption/output anomaly suggests that for most questions calling for an international version of the neoclassical business cycle framework, further theoretical development is needed. An example of such a question is whether the possibility of international trade alters our assessment of the importance of technology shocks for aggregate fluctuations. In open economies, additional sources of shocks may be more important than they have been in closed economies. Other questions for international business cycle theory concern the behavior of relative prices of international goods, comovements between relative prices and the balance of trade, and the international comovements of consumption and output. Clearly these questions require modification or extension of the theoretical structure studied in this paper. Recent examples include asymmetries of country size in Baxter and Crucini (1991), additional sources of shocks in Cardia (forthcoming), alternative preference relations in Devereux, Gregory, and Smith (forthcoming) and Mendoza (1991), and multiple produced and traded goods in Ravn 
(1990) and Stockman and Tesar (1990). It remains to be seen whether these features can provide a persuasive resolution of the consumption/output anomaly.

All of these papers focus on the behavior of stochastic growth models at business cycle frequencies. A complementary issue is the ability of these models to account for comovements at low frequencies. We observe, for example, that poor but quickly growing countries borrow less from richer, more slowly growing countries than theory suggests. This and other low-frequency discrepancies between theory and data provide additional topics for further work. 


\section{APPENDIX}

\section{DATA SOURCES}

The business cycle properties documented in tables 1 and 2 are based on data from two sources: table 1 on Citibank's Citibase and table 2 on the International Monetary Fund's International Financial Statistics (IFS). The Solow residuals examined in Section III also used labor data published by the Organization for Economic Cooperation and Development (OECD). Details follow.

Table 1. The series (description, Citibase mnemonic) are output (gross national product, GNP82), consumption (personal consumption expenditures on nondurables and services, CN82+CS82), fixed investment (gross private domestic fixed investment, GIF82), hours (manhours of the employed labor force from the household survey, LHOURS), capital stock (net capital stock for nonresidential fixed investment, KN72 from an older Citibase tape), inventory stock (stock of nonfarm inventories, GLN82), and net exports/output (ratio of current-dollar net exports of goods and services to currentdollar GNP, GNET/GNP). With the exception of the ratio of net exports to output, which is based on current prices, and the capital stock, which is in 1972 prices, all series are in 1982 prices.

Table 2. The series (description, IFS line number) are consumption (private consumption, 96f, divided by the output deflator), savings rate (ratio of nominal output minus private and government consumption, $99 x-96 f$ - 91f, to nominal output), investment rate (ratio of gross fixed capital formation, 93e, to nominal output), and net exports/output (ratio of exports minus imports of goods and services, 90c - 98c, to nominal output). On the IFS tape, all series but real output are nominal. We deflated them, as stated, with the output deflator, computed as the ratio of nominal to real output. The nominal output series are $99 x$, with $x=a$ or $b$ as described below. The real output series are real GNP or GDP, labeled $99 x . y$, for $x=a$ or $b$ and $y=p$ or $r$. The suffixes denote the output concept (GNP or GDP) and seasonal adjustment: $x=a$ 
indicates GNP, $\mathrm{x}=\mathrm{b}$ indicates GDP, $\mathrm{y}=\mathrm{r}$ indicates seasonally adjusted, $\mathrm{y}=\mathrm{p}$ indicates not seasonally adjusted. The output series are GNP for Canada, Germany, Japan, and the United States, GDP for the rest. With the exception of Australia, Austria, and Finland, the data are seasonally adjusted. We seasonally adjusted the data for these countries by the $\mathrm{X}-11$ method.

The European aggregates for output and consumption are sums of real quantities for the European countries: Austria, Finland, France, Germany, Italy, Switzerland, and the United Kingdom. We use Summers and Heston's (1988) data on real output and consumption in international prices for 1985 to translate real output and consumption into comparable units. The idea is to multiply each series by a constant chosen to match the average value of the series in 1985 to the Summers-Heston number. The Summers-Heston number for real output in 1985 is the product of per capita GDP and population (variables 2 and 1 in their Table 3 ). The number for real consumption is the product of per capita GDP, population, and the consumption share (variables 2, 1, and 3 of the same table). European output and consumption are the sums of the individual country series after translation.

Solow Residuals. We constructed Solow residuals for the United States, Canada, and a European aggregate from real output and labor input by the formula:

$$
\log \lambda_{t}=\log y_{t}-(1-\theta) \log n_{t}
$$

with $\theta=0.36$. The output series is real output from the IFS tape, as described above. The labor input variable is civilian employment, from DRI's OECD Main Economic Indicators data base. The European aggregate includes Austria, Finland, Germany, Italy, Switzerland, and the United Kingdom. We excluded France, because it did not collect labor data according to ILO standards in the 1960s and 1970s and because the OECD does not report civilian employment in France until 1981. The European labor aggregate is the sum of the values for the individual countries, measured in thousands of workers. The 
European output aggregate is analogous to the one used in table 2, with France omitted. Before estimating the technology process, we scaled each estimate of $\lambda$ to give it a sample mean of one. 


\section{References}

Backus, David K., and Kehoe, Patrick J. "International Evidence on the Historical Properties of Business Cycles." Manuscript. Minneapolis: Federal Reserve Bank of Minneapolis, June 1988.

Baxter, Marianne, and Crucini, Mario. "Explaining Saving/Investment Correlations." Manuscript. Rochester: University of Rochester, May 1991.

Cantor, Richard, and Mark, Nelson C. "The International Transmission of Real Business Cycles." International Economic Review 29 (August 1988): 493-507.

Cardia, Emanuela. "The Dynamics of a Small Open Economy in Response to Monetary, Fiscal, and Productivity Shocks." Journal of Monetary Economics, forthcoming.

Christiano, Lawrence J. and Eichenbaum, Martin. "Current Real Business Cycle Theories and Aggregate Labor Market Fluctuations." Manuscript. Cambridge, Mass.: National Bureau of Economic Research, October 1988.

Cole, Harold, and Obstfeld, Maurice. "Commodity Trade and International Risk Sharing: How Much Do Financial Markets Matter?" Journal of Monetary Economics 28 (August 1991): 3-24.

Danthine, Jean Pierre, and Donaldson, John. "Methodological and Empirical Issues in Real Business Cycle Theory." European Economic Review, forthcoming.

Dellas, Harris. "A Real Model of the World Business Cycle." Journal of International Money and Finance 5 (September 1986): 381-94.

Devereux, Michael; Gregory, Allan; and Smith, Gregor. "Realistic Cross-Country Consumption Correlations in a Two-Country, Equilibrium, Business Cycle Model." Journal of International Money and Finance, forthcoming.

Dooley, Michael; Frankel, Jeffrey; and Mathieson, Donald J. "International Capital Mobility: What Do Saving-Investment Correlations Tell Us?" International Monetary Fund Staff Papers 34 (September 1987): 503-30. 
Eichenbaum, Martin S.; Hansen, Lars Peter; and Singleton, Kenneth J. "A Time Series Analysis of Representative Agent Models of Consumption and Leisure Choice Under Uncertainty." Quarterly Journal of Economics 103 (February 1988): 51-78.

Feldstein, Martin, and Horioka, Charles. "Domestic Saving and International Capital Flows." Economic Journal 90 (June 1980): 314-29.

Hansen, Gary D. "Indivisible Labor and the Business Cycle." Journal of Monetary Economics 16 (November 1985): 309-327.

Hodrick, Robert J., and Prescott, Edward C. "Post-War U.S. Business Cycles: An Empirical Investigation." Pittsburgh: Carnegie Mellon University, November 1980. Hotz, V. Joseph; Kydland, Finn E.; and Sedlacek, Guilherme L. "Intertemporal Preferences and Labor Supply." Econometrica 56 (March 1988): 335-360.

King, Robert G., and Sergio Rebelo. "Low Frequency Filtering and Real Business Cycles." Manuscript. Rochester: University of Rochester, October 1989.

Krugman, Paul R., and Baldwin, Richard E. "The Persistence of the U.S. Trade Deficit." Brookings Papers on Economic Activity 1 (1987): 1-43.

Kydland, Finn E., and Prescott, Edward C. "Time to Build and Aggregate Fluctuations." Econometrica 50 (November 1982): 1345-70.

Kydland, Finn E., and Prescott, Edward C. "The Workweek of Capital and Its Cyclical Implications." Journal of Monetary Economics 21 (March/May 1988): 343-60.

Kydland, Finn E., and Prescott, Edward C. "Business Cycles: Real Facts and a Monetary Myth." Federal Reserve Bank of Minneapolis Quarterly Review (Spring 1990): 3-18.

Mantel, Rolf R. "The Welfare Adjustment Process: Its Stability Properties." International Economic Review 12 (October 1971): 415-30.

Mendoza, Enrique G. "Real Business Cycles in a Small Open Economy." American Economic Review 81 (September 1991): 797-818.

Negishi, Takashi. "Welfare Economics and Existence of an Equilibrium for a Competitive Economy." Metroeconomica 12 (August-December 1960): 92-97. 
Obstfeld, Maurice. "Capital Mobility in the World Economy: Theory and Measurement." Carnegie-Rochester Conference on Public Policy 24 (Autumn 1986): $55-103$.

Prescott, Edward C. "Theory Ahead of Business-Cycle Measurement." CornegieRochester Conference on Public Policy 25 (Autumn 1986): 11-44; reprinted in the Federal Reserve Bank of Minneapolis Quarterly Review (Autumn 1986): 9-22.

Ravn, Morten O. "The Balance of Trade in Real Business Cycles." Manuscript. University of Southampton, 1990.

Scheinkman, Jose. "General Equilibrium Models of Economic Fluctuations: A Survey of Theory." Manuscript. Chicago: University of Chicago, June 1984.

Solow, Robert M. "Technical Change and the Aggregate Production Function." Review of Economics and Statistics 39 (August 1957): 312-20.

Stockmạn, Alan C. and Svensson, Lars E. O. "Capital Flows, Investment, and Exchange Rates." Journal of Monetary Economics 19 (March 1987): 171-201.

Stockman, Alan C. and Tesar, Linda L. "Tastes and Technology in a Two-Country Model of the Business Cycle." Manuscript. Rochester: University of Rochester, November 1990.

Summers, Robert, and Heston, Alan. "A New Set of International Comparisons of real Product and Price Levels." Review of Income and Wealth 34 (March 1988): 1-25. Taylor, Stephen. "World Payments Imbalances and U.S. Statistics." In The Measurement of Saving, Investment, and Wealth, Studies in Income and Wealth, Volume 52, edited by R.E. Lipsey and H.S. Tice. Chicago: University of Chicago Press, 1989.

Tesar, Linda L. "Savings, Investment, and International Capital Flows." Journal of International Economics 31 (August 1991): 55-78. 
Table A.1

Data for Weights

Austria

pop pc gdp cons share

Finland

$\begin{array}{lll}7.555 & 8929 & 0.6270\end{array}$

$\begin{array}{lll}4.908 & 9232 & 0.5226\end{array}$

France

$\begin{array}{lll}55.172 & 9918 & 0.6570\end{array}$

Germany

$\begin{array}{lll}61.015 & 10708 & 0.5434\end{array}$

Italy

$\begin{array}{lll}57.128 & 7425 & 0.6264\end{array}$

Switzerland

$\begin{array}{lll}6.458 & 10640 & 0.6577\end{array}$

United Kingdom

$\begin{array}{lll}56.543 & 8665 & 0.5971\end{array}$ 


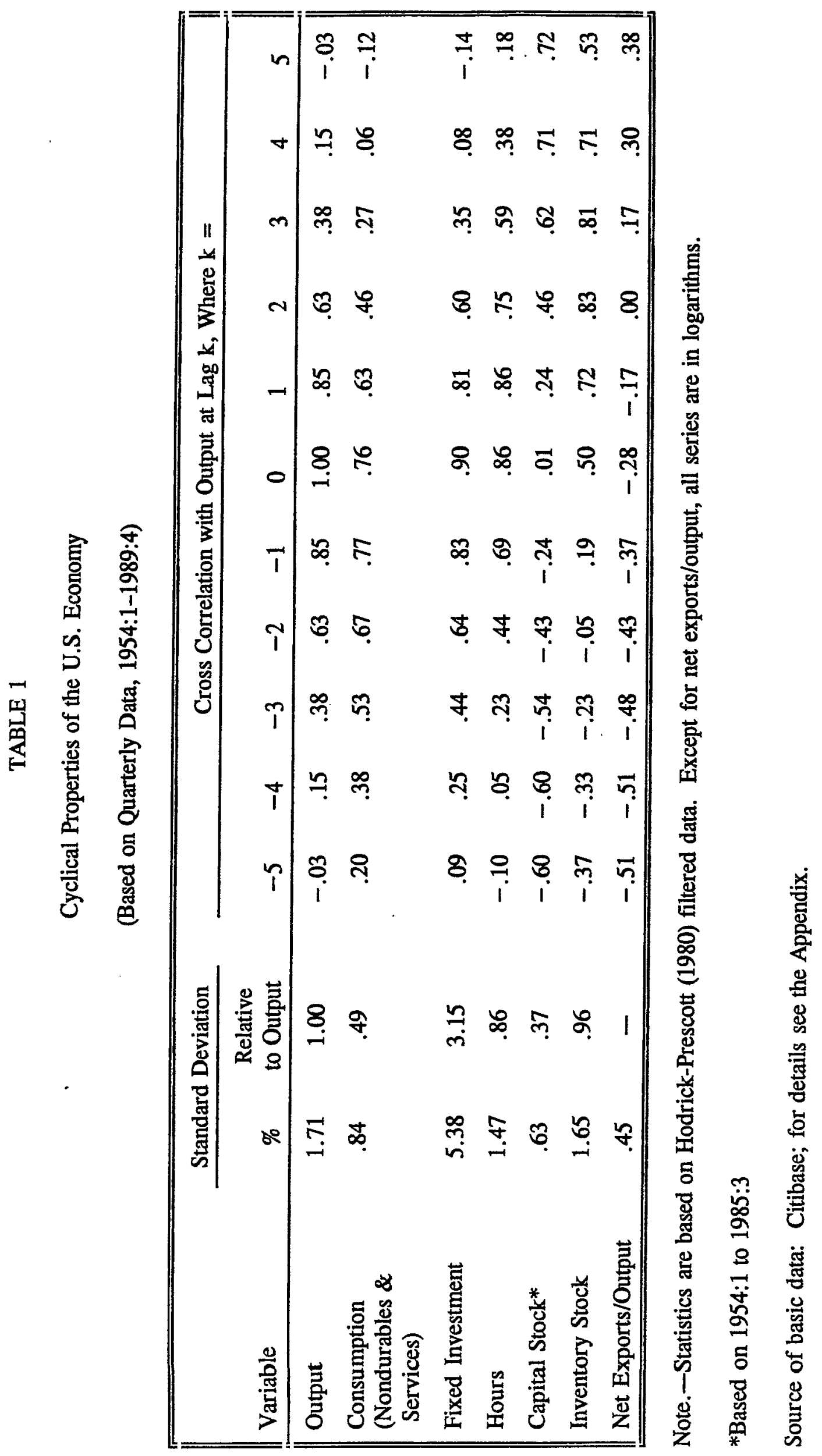


TABLE 2

International Comovements

\begin{tabular}{|c|c|c|c|c|c|}
\hline \multirow[b]{3}{*}{ Country } & \multicolumn{4}{|c|}{ Contemporaneous Cross-Correlations } & \multirow{3}{*}{$\begin{array}{c}\text { Standard } \\
\text { Deviation (\%) }\end{array}$} \\
\hline & \multicolumn{2}{|c|}{$\begin{array}{c}\text { With Same U.S. } \\
\text { Variable }\end{array}$} & \multicolumn{2}{|c|}{ Within Each Country } & \\
\hline & Output & Consumption & $\begin{array}{c}\text { Saving Rate With } \\
\text { Investment Rate }\end{array}$ & $\begin{array}{l}\text { Net Exports/Output } \\
\text { With Output }\end{array}$ & \\
\hline Australia & .25 & .13 & -.07 & -.11 & 1.37 \\
\hline Austria & .31 & .07 & .29 & -.42 & 1.12 \\
\hline Canada & .77 & .65 & .06 & -.29 & .79 \\
\hline Finland & .02 & -.01 & .09 & -.36 & 1.96 \\
\hline France & .22 & -.18 & -.04 & -.17 & .83 \\
\hline Germany & .42 & .39 & .42 & -.27 & .85 \\
\hline Italy & .39 & .25 & .06 & -.62 & 1.41 \\
\hline Japan & .39 & .30 & .50 & -.03 & .89 \\
\hline $\begin{array}{l}\text { South } \\
\text { Africa }\end{array}$ & -.15 & -.23 & -.60 & -.56 & 3.35 \\
\hline Switzerland & .27 & .25 & .38 & -.66 & 1.47 \\
\hline U.K. & .48 & .43 & .07 & -.21 & 1.10 \\
\hline U.S. & 1.00 & 1.00 & .68 & -.36 & .42 \\
\hline Europe & .70 & .46 & - & - & - \\
\hline
\end{tabular}

Note.--Statistics are based on Hodrick-Prescott (1980) filtered data. Output and consumption are in logarithms. Sample period for Australia is 1960:1-1989:4; Austria, 1964:1-1990:1; Canada, 1960:1-1989:3; Finland, 1970:1-1988:2; France, 1965:1-1989:4; Germany, 1960:1-1989:4; Italy, 1970:1-1987:3; Japan, 1965:1-1990:1; South Africa, 1960:1-1989:4; Switzerland, 1967:1-1986:4; United Kingdom, 1960:1-1990:1; United States, 1960:1-1990:2; and Europe, 1970:1-1986:4. Correlations are computed from observations available for both series.

Source of basic data: IFS, for details see the Appendix. 


\section{TABLE 3}

\section{Benchmark Parameter Values}

\begin{tabular}{|ll}
\hline Preferences & $\beta=.99, \mu=.34, \quad \gamma=-1.0, \alpha=1$ \\
Technology & $\theta=.36, \quad \nu=3, \quad \sigma=.01$, \\
& $\delta=.025, \mathrm{~J}=4$ \\
Technology Shocks & $\mathrm{A}=\left[\begin{array}{ll}\mathrm{a}_{11} & \mathrm{a}_{12} \\
\mathrm{a}_{12} & \mathrm{a}_{11}\end{array}\right]=\left[\begin{array}{ll}.906 & .088 \\
.088 & .906\end{array}\right]$ \\
& \\
& $\operatorname{var} \epsilon^{\mathrm{h}}=\operatorname{var} \epsilon^{\mathrm{f}}=.00852^{2}, \operatorname{corr}\left(\epsilon^{\mathrm{h}}, \epsilon^{\mathrm{f}}\right)=.258$ \\
\hline
\end{tabular}




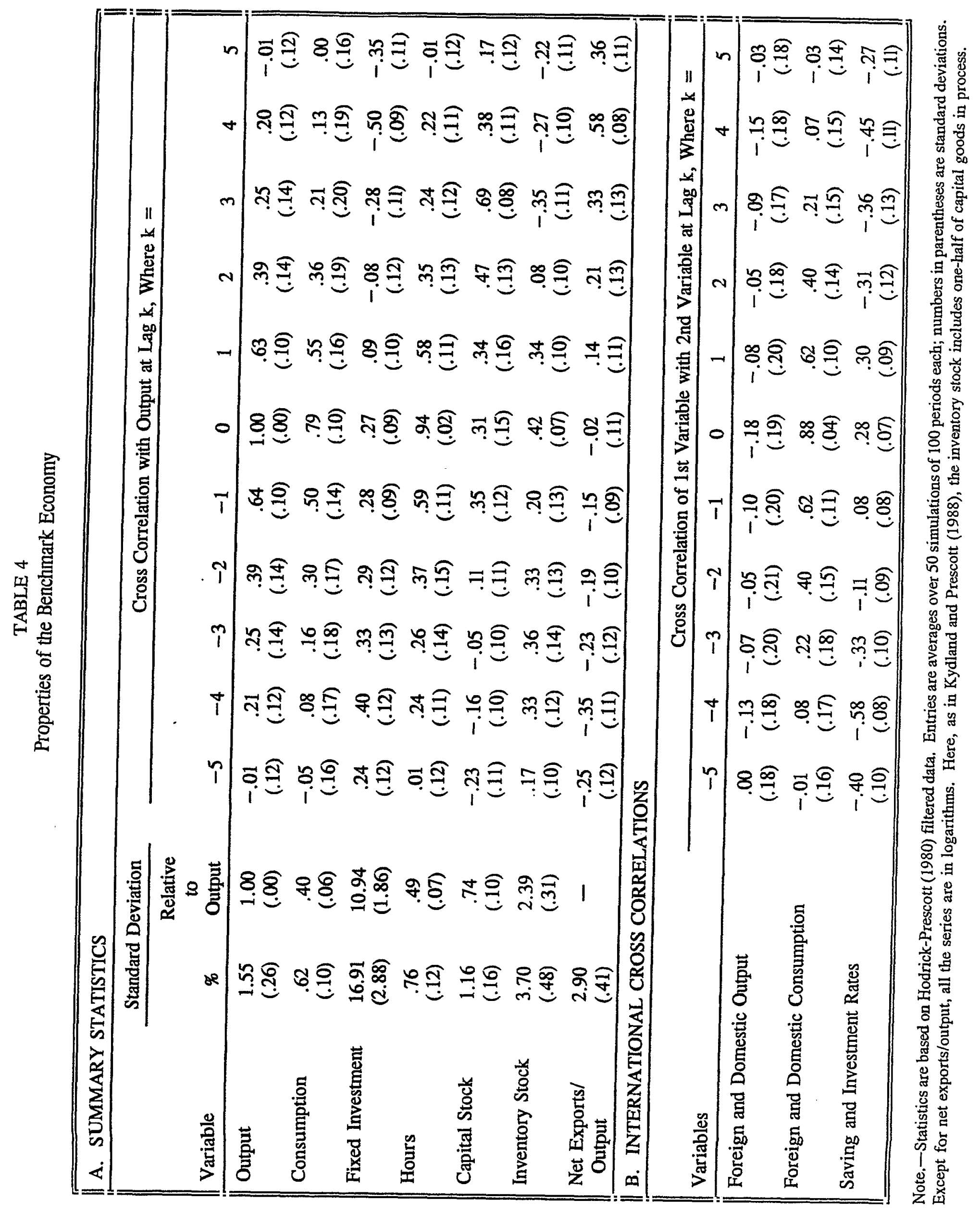




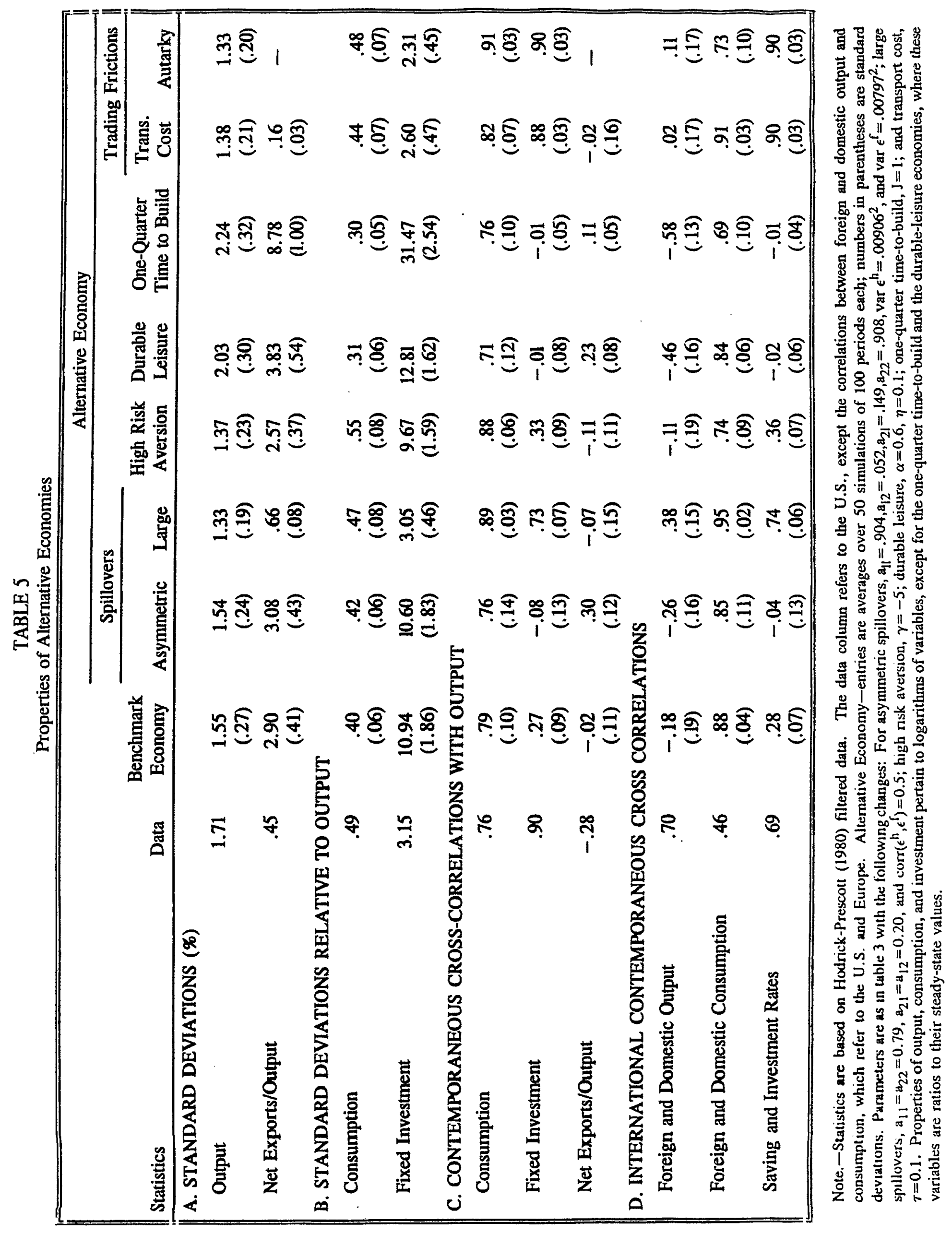


Figure 1: An example of a U.S. time series detrended with the Hodrick-Prescott Filter

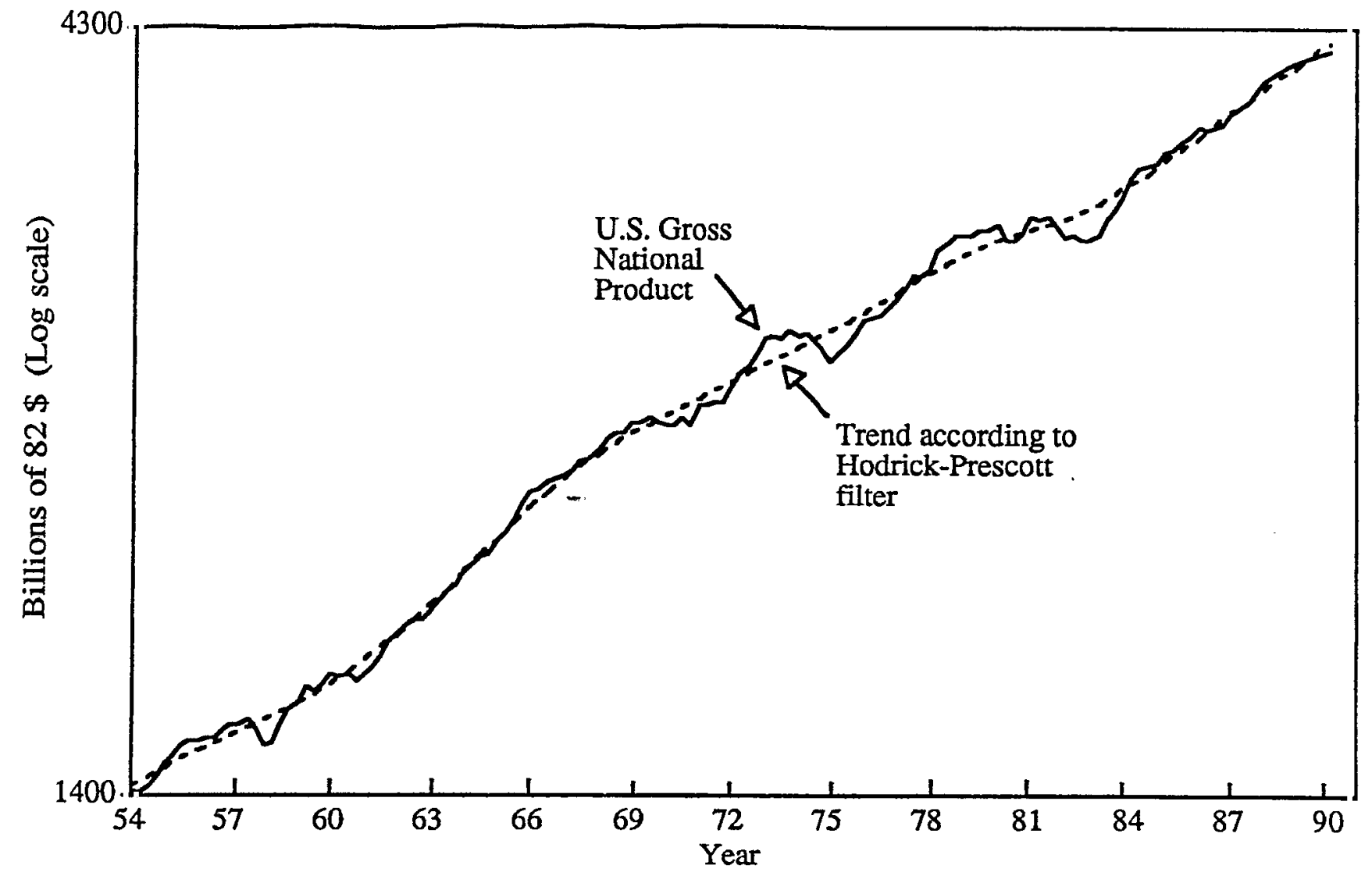

Source: Citibase 

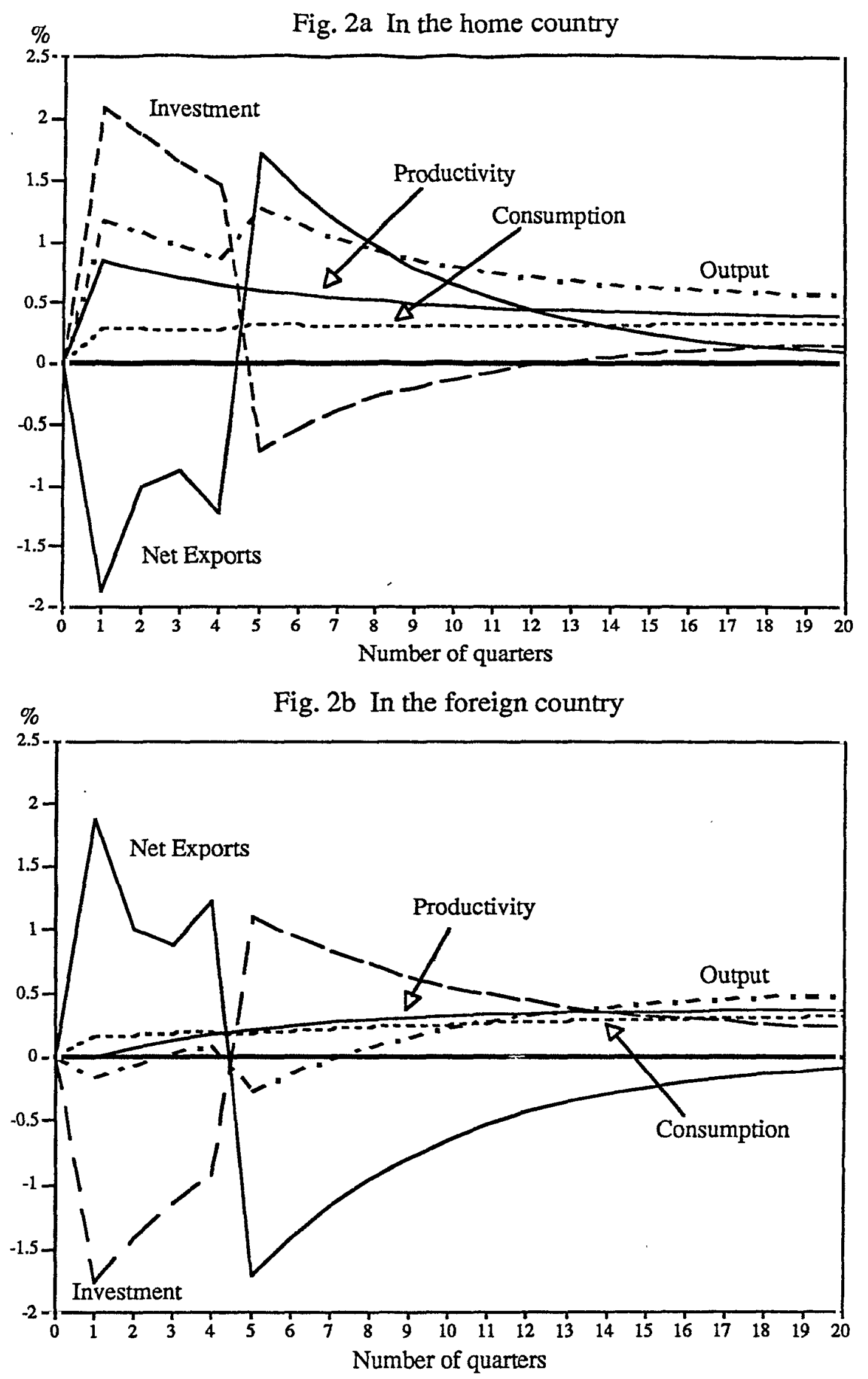

Figure 2: Dynamic responses to a one standard deviation innovation in the home country's technology shock in the benchmark (free trade) economy. (Productivity is measured as a percent of its steady state value. All other variables are measured as a percent of steady state output.) 

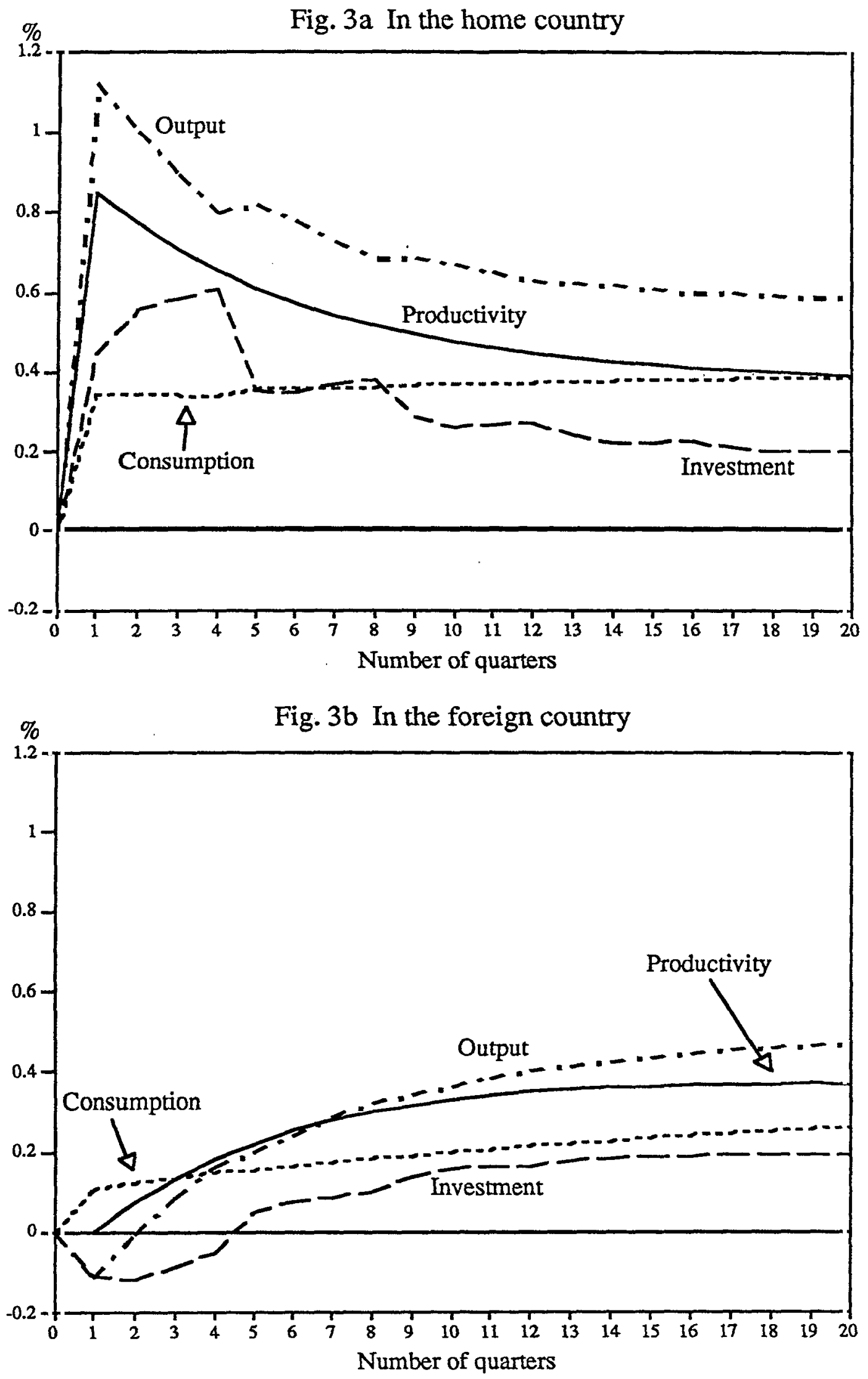

Figure 3: Dynamic responses to a one standard deviation innovation in the foreign country's technology shock in the autarky economy. (Productivity is measured as a percent of its steady state value. All other variables are measured as a percent of steady state output.) 